\title{
Power market: effects of the imperfect competition
}

\author{
Carlos Redondo Gil, Ana M. Alonso Sánchez, Luis A. Esquibel Tomillo y Álvaro Fernández Suárez. \\ Department of Electrical and Electronic Engineering. \\ Industrial and Computer School of Engineerings (E.II.I.I.). University of Leon. \\ Edificio Tecnológico. Campus de Vegazana s/n. 24071-León (Spain). \\ Phone.: +34987291786e-correo: carlos.redondo.gil@unileon.es
}

\begin{abstract}
In the current technological and economic frame the market of the electrical power [JANE05 $]^{1}$ is defined in the practice as a prototype of Natural Monopoly in spite of the attempts of intervention put into practice in Spain. The attempt of promotion (Board 2001/77/CE of the European Parliament and of the Advice, of September 27, 2001) of the electricity generated from renewable sources of energy in the domestic market of the electricity ${ }^{2}$ is defined as one of the policy ones of intervention faced to compensate the imperfection of the competition across the support to the establishment of new companies that act on monopolistic markets across the authorization of subsidies and/or financial and fiscal facility.

The present document tackles the definition of the most significant aspects of the market of the electrical energy from the perspective of the same one as a natural monopoly and the quantification in relative terms of the loss of social well-being in environments of imperfection of the competition and mistakes of the market.
\end{abstract}

The proposed conclusions define a critical stage with the current state of design of strategic and operative plans and an inefficient politics of innovation and development.

\section{Key words}

Energy market. Imperfection of the competition. Natural monopoly. Loss of social well-being.

\section{Introduction}

The regulatory strategies destined to promote of direct and clear form to the renewable energies supported in the European Union can be classified in accordance with two basic criteria, in the first instance in the sense of if the regulatory interventionism reverberates on the price or on the aptitude to install, and in the second instance if the measurements of intervention act on the investment or on the generation.

In accordance with such criteria, the interventionism can materialize regulating the price, good across fiscal helps or by means of financial support for $\mathrm{kW}$ of installed potency, or across the payment of a certain quantity for $\mathrm{kWh}$ renewable generated and delivered to the network,

${ }^{1}$ The Gazette of the Business, Núm. 4.993, 26 September, 2005.

${ }^{2}$ [Newspaper Official L 283 de 27.10.2001] leaving in hands of the market the determination of the quantity of generation to install.

Of alternative form, the regulatory interventionism can be praised for establishing with policy criteria the absolute or relative level of potency generated as target to reach, leaving in hands of the market the determination of the price. In the attached table they qualify and simplify the regulatory strategies destined to promote politically and to promote the renewable energies.

\begin{tabular}{lll} 
& $\begin{array}{l}\text { Controlled factor: } \\
\text { PRICE }\end{array}$ & $\begin{array}{l}\text { Controlled factor: } \\
\text { QUANTITY } \\
\text { (INSTALLED } \\
\text { POTENCY) }\end{array}$ \\
\hline $\begin{array}{l}\text { Strategy based } \\
\text { on the investment }\end{array}$ & $\begin{array}{l}\text { Subsidy to the investment } \\
\text { Tax allowance }\end{array}$ & Auction \\
\hline $\begin{array}{l}\text { Strategy based } \\
\text { on the generation }\end{array}$ & $\begin{array}{l}\text { Tariffs of introduction of renewable } \\
\text { energy in the electrical network } \\
(R E F I T)\end{array}$ & $\begin{array}{l}\text { Quotas more } \\
\text { Certified Greens }\end{array}$ \\
& &
\end{tabular}

Table 1 . Regulatory strategies for the promotion of renewable energies

In the first quadrant there are defined the proper mechanisms of a strategy of interventionism destined to promote the establishment of new companies, or since it is the case to encourage processes of diversification and technological innovation, in a context of markets of imperfect competition.

The big electrical companies move back from the liberalized market due to the high price of the MWh in the pool and as consequence of the so called deficit of tariff, in extract a legal device that allows to the companies of the sector to bring together the deficit derived from the official tariffs manipulating the system: an electricity company offers first of all his cheapest energy $-v g$. central hydraulics - and in last place the most expensive $-v g$. head office of combined cycle being the energy of the highest marginal price the one that marks the definite price of the MWh of the pool. Artificially it is possible to use the biggest cost of production of the energies proceeding from certain renewable sources, to go on from the strategies of support, to determine the price of the pool, compared by the Spanish legislation with the cost of production of the energy, generating a deficit of tariff to charge in the future independently of the real increase of costs. 


\section{The natural monopoly}

When the last events of the market reveal that the principal electrical companies of Spain are moving back from the liberalized market of the electrical energy (for all kinds of clients, big consumers including), it is necessary to rethink that the electrical sector keeps on being a clear and significant example of what is known as Natural Monopoly. There exist certain services which imperfect markets do that technically the situation of major efficiency is a monopoly. There exist certain services which imperfect markets do that technically the situation of major efficiency is a monopoly. Example type of this situation is the electrical market recently liberalized in Spain and that the passage of time, the artful application of the law and the interested use of the new sources of energy has returned to the situation

A natural monopoly is an imperfection of the market of free competition. In certain situations a company is subject to wide economies of scale as regards the capacity of absorption of the market in the one that acts, in such a way that his average cost of production is decreasing for levels of production capable of being absorbed by the market. It is in this type of situations when it is advised (due to the productive efficiency) that the supply realizes for the only company (natural monopoly) since of not being like that one would incur a few substantially higher costs of production.

The fundamental reason of the natural monopoly is not different that a technological reason. There exist certain services that to be offered it is necessary that the company loaner of the services realizes strong investments in necessary infrastructures to be able to operate on this market. The market of the electrical energy is defined, and based on the current evolution of the markets it has been consolidated in spite of the attempts of structure on a regular market produced by the distributors and of a liberalized market produced by the departments of commercialization (both buy the energy in the pool), as an example of this type of markets. This type of products or services are characterized by a few high fixed costs for the production and a few variable low costs compared to the fixed special costs, which forces to support a production higher that the market could absorb to be able to diminish the average cost.

See as illustrative example the production, distribution and commercialization of the electrical conventional energy and certain types of electrical energy obtained from renewable sources in particular hydroelectrics. The current conditions of the market do that the departments of commercialization of the big groups compensate the losses with the extra income of the generating ones thanks to the prices of the pool doing except that any megawatt sold without having being produced provokes irrecoverable losses. The technological circumstances that meet in this type of situations demand as condition necessary, although not sufficient, for the economic efficiency that the market should structure in a diet of monopoly of offer.
Therefore, and in view of the exposed thing, it can be established that on markets characterized for this structure of costs, markets that also operate with products and/or services of the first need, the increase of companies loaners of the service propitiates an increase of the average cost what involves inevitably an increase in the tariffs that the clients have to pay. All this implies a decrease of the social well-being of the users of the service capable of quantification.

The exposition of the problem that represent the natural monopolies can define with clarity from the conclusions derived from the analysis of the Graph 1.

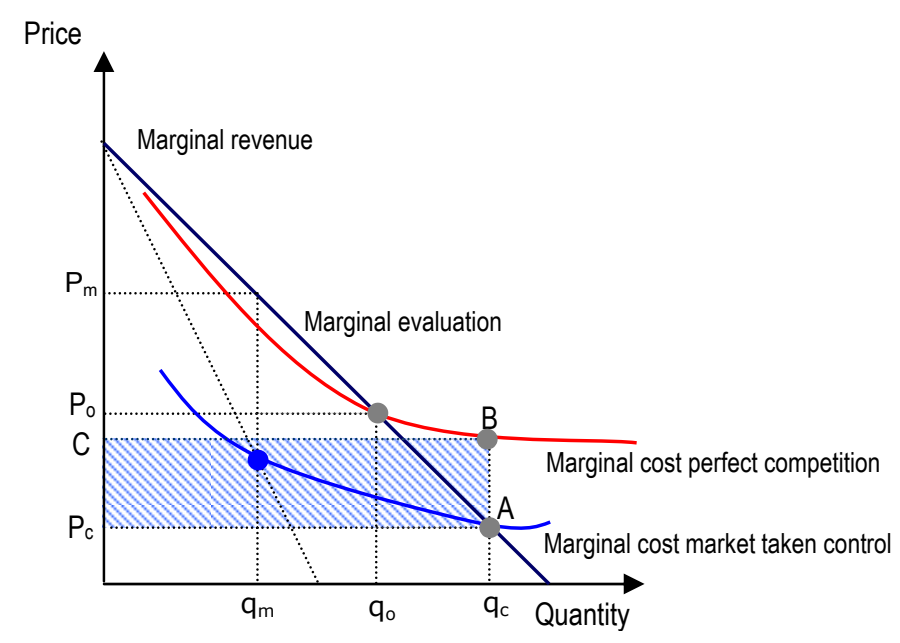

Graph 1. Relation quantity / price / cost

The capacity of absorption of the product that presents the demand of the market does not exhaust the economies of scale that there offers the structure of monopolistic costs of the company, characteristic that it defines of the Natural Monopolies.

In this type of problems we can meet three differentiated cases.

1. There is no type of governmental regulation. In this case the monopolistic company will try to maximize the benefit and he was adopting a level of production $\mathrm{q}_{\mathrm{m}}$ that will be a such level that the marginal cost and the marginal revenue would be equal. The price of sale will be $P_{m}$. Since the market is deduced of this situation it would make the potential clients defenseless since the monopolistic company of the services would restrict strongly the level of production (much underneath of the quantity capable of being absorbed by the market) and therefore he would place to the market in a high price (law of supply and the demand). In addition to this, it is deductible that for a level of production $q_{m}$ the marginal cost $[\mathrm{BAUM} 70]^{3}$ is below the marginal evaluation what is an unequivocal sign that it is possible to increase the level of social well-

\footnotetext{
${ }^{3}$ BAUMOL, W., y BRADFORD, “Optimal Departures from Marginal Cost Bricing”, American Economic Review, Vol. 60, June, 1970, pp. 265283.
} 
being. This would be obtained increasing the level of production. For the sake of this increase of social well-being a politics of intervention is justifiable on the part of the state.

2. Governmental intervention in accordance with the criterion of Pareto [MISH72] ${ }^{4}$ with which the marginal cost makes be coincided with the marginal evaluation. This corresponds at a level of production $\mathrm{q}_{\mathrm{c}}$ to which a price corresponds $P_{C}$. An intervention of this type turns out to be problematic since the monopolistic company would incur losses. The quantity of the above mentioned losses quantified by the area ABCPC. Lost these will have to be compensated somehow for the state that decides to apply a politics of intervention of this type. This compensation will have to come in the shape of subsidy or in the shape of budgetary endowment and in quantity not lower than the quantified one by the area ABCPC. Consequently, it is possible that the theoretical efficiency that is obtained of the balance $\mathrm{q}_{\mathrm{c}}$ causes a loss of efficiency of equal, minor or major quantity in another Market or markets as consequence of a possible tax well-established route. Another possible problem that this type can transport of policy fond at the distributive level of the tax politics that supposedly should be implanted. We want to say with it, that it is possible that the users of a service are subsidized indirectly on the part of all the taxpayers, even on the part of the users of other services who have to see nothing.

3. The third option is to adopt a level of production $\mathrm{q}_{\mathrm{o}}$ derivative of equaling the function of average cost and that of average revenue (function of demand) $[\mathrm{COAS} 46]^{5}$, loading an equal price on the average cost $P_{0}$. With it there is obtained an immediate solution that demands that the monopolist should increase his level of production over the level that would make him maximize his benefits $\left(q_{m}\right)$ not even extraordinary benefits being obtained not even provoking losses problems of financing being avoided this way.

\section{The loss of social well-being of the Monopoly}

The monopoly of the offer of a product or service is a model of imperfection of the competition that drives from inevitable form to a loss of the social well-being. Reaffecting in the exposition, a monopoly of offer that tends to maximize the benefits would drive to a wrong and inefficient allocation of resources [RAWL71] $]^{6}$.

\footnotetext{
${ }^{4}$ Mishan, E. J., "The futility of Pareto-Efficient Distribution ".

American Economic Review, 62, December 1972, pp. 971-976.

${ }^{5}$ COASE, R. H., "The marginal cost Controversy ". Economica, New series, vol 13, 1946

${ }^{6}$ RAwls, J., "A theory of Justice ". Harvard UP, Cambridge, Mass., 1971.
}

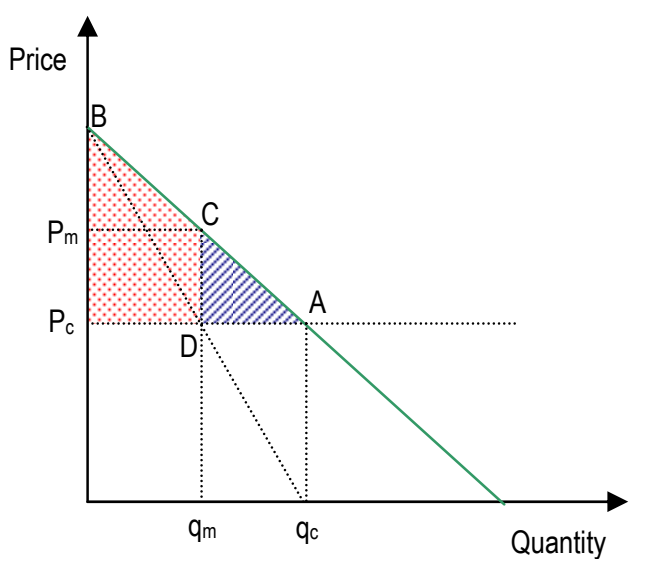

Graph 2. Loss of social well-being.

If the company loaner of a service or product was acting as agent that it tends to maximize would produce a quantity $q_{m}$ and it will sell at a price $P_{m}$, but the level of production $\mathrm{q}_{\mathrm{m}}$ is not an efficient level since the marginal cost is very lower than the marginal evaluation.

A comparison between the situation of balance $\mathrm{q}_{\mathrm{c}}$ and $\mathrm{q}_{\mathrm{m}}$ is useful at the time of justifying the so-called loss of social well-being of the monopoly. In case of a balance competitive (that is to say, with a production of $q_{c}$ ) the surplus of the consumer who results from the deal is represented by the triangle BAPC. In the assumption of balance of competition (that is to say with a production $\mathrm{q}_{\mathrm{m}}$ ), it departs from that surplus of the consumer surplus stays as such (it is the area BCPm) and another part turns into extraordinary benefits of the monopolist (it is the area PmCDPc) and, finally, there is a part that gets lost that it is the area of the triangle CAD. The last one can be considered to be an index of the loss of social well-being that bears the monopoly compared to an efficient allocation of resources that would be obtained in case the market was working in a situation of perfect competition. This loss of social well-being can be considered to be an argument cost to justify a state intervention in this type of market.

\section{Conclusions}

Beforehand the technological circumstances that meet in situations marked by the accented disparity between the fixed costs and the variable costs so that the average costs diminish undiscontinuously as it increases the production in the whole ambience of the quantity of of the product that can be absorbed by the Market, they

\footnotetext{
${ }^{7}$ It has to be born in mind that for the making of the graph there have considered the average constant costs (what he wants to say that anyone that should be the level of production the cost of production will be the same)
} 
demand as condition necessary, although not sufficient, for the economic efficiency that the market should structure in a diet of monopoly of offer.

A monopoly of offer that it tends to maximize of benefits drives inevitably to the respective market to an inefficient allocation of resources.

As general norm the capacity of absorption of the product, energy of consumption, which presents the demand of market does not exhaust the economies of scale that there offers the cost structure of the monopolistic, typical company that defines exactly the natural monopolies.

The definition of policy of intervention, see, (1). programs of nationalization of the industry where there exists the risk that the company neglects the efficiency of the productive process incurring an elevation of the managerial costs; (2) I develop of policy tax, well a canon for license, well a tax for unit of product or a tax on extraordinary benefits that as general norm rarely help to solve the problem of the said inefficiency in the process of allocation of resources; (3) to promote the establishment of new companies or systems or productive differentiated processes, in our case use of new sources of energy - renewable energies - across subsidies or financial or fiscal facility with the risks that the help needed by the new companies they support during indefinite time and (4) fixation of maximum prices. Any of four measurements needs the development of a legislative action supporting laws against the restrictive practices of the competition.

As general norm the development of policy antitrust causes managerial top costs that imply the development of strategic and operative plans destined to support the survival in the short term leaving a planning in longer term that he would allow to design and to develop projects of $\mathrm{I}+\mathrm{D}+\mathrm{i}$ with which to reach a major efficiency of functioning.

Nevertheless everything above mentioned and despite the possible criticism to policy antitrust as persons in charge of the disincentive position for the development of innovative efforts and policy minimally aggressive of managerial growth, it is clear that, before the absence of competition on the markets, the extraordinary benefits to which a certain monopolistic power gives place on the market not necessarily cause, since it demonstrates the experience, policy of $\mathrm{I}+\mathrm{D}$ in technological piece of news and organizational models, really hardly it is necessary to hope that the extraordinary benefits should be used to finance the development of the most advanced technologies, situation that clearly defines the industrial sector of production, distribution and commercialization of the electrical energy.

The current regulatory Spanish frame, which identifies the price pool with the cost of production of the energy, allows to define the deficit of tariff as a legal device that allows the companies of the sector, using the biggest costs of production of the energy obtained from renewable sources, to compensate the risk of deficit caused by the incapability of the official tariff of covering one increases of the costs. The deficit of tariff allows to take into account the imbalance of his account of results of development as a debt that actually does not correspond with the real losses produced by the increase of the costs of production. The Spanish legislation allows the companies to recover the deficit of an exercise loading it against the tariffs of the following one so that accumulating a big deficit it is possible to force an increase of the same ones.

\section{Acknowledgement}

This work was supported by the Renewable Energies Chair of the University of Leon. Economy and Employment Government Department (Castilla y León Autonomous Region). Energy and Mines Department.

\section{References}

[BAUM70] BAUMOL, W., y BRADFORD, “Optimal Departures from Marginal Cost Bricing", American Economic Review, Vol. 60, June, 1970, pp. 265-283.

Bонм, P., "Social efficiency: A concise introduction to welfare economics", Macmillan Press Ltd., 1977.

[COAS46] COASE, R. H., "The marginal cost Controversy ". Economica, New series, vol 13, 1946.

[JANE05] JANER, M.; "Energía". The Gazette of the Business, Num. 4.993, 26 September, 2005.

Keller, R.; " The Social Balance ", in papers and communications the Ist Congress of A.E.C.A.: Institute of Countable Planning. Treasury Department. Pp. 517-522, Madrid, 1983.

LEWIS, W. A., "Fixed costs ". Economic, New series, vol. 13, 1946.

LiTTLE, I. M. D., "Critique of Welfare Economics ". Oxford University Press, Oxford, 1960.

[MISH72] Mishan, E. J., "The futility of Pareto-Efficient Distribution ". American Economic Review, 62, December, 1972, pp. 971-976.

OKun, A. M., "Equity and efficiency: The big trade off ". Brokings, Whashinton, 1975, p. 112.

ORR, L. L., "Incose transfers as Public food: An Application to $A F D C$ ". American Economic Review, 66, n³, June, 1976, pp. 359-371.

[RAWL71] RAWLS, J., "A theory of Justice ". Harvard UP, Cambridge, Mass., 1971.

THurow, L. C.,"The income distribution as a pure public Good ". Quarterly Journal of Economics, 85, May, 1971, pp. 327-336.

ToBIN, J., "On limiting the domain of Ineguality ". Journal of Law and Economics, 13, October, 1970.

ZeCKHAVSER, R. J., "Optimal Mechanism for income Transfers". American Economic Review, 61, June, 1971, pp. 324-334. 